\title{
EVALUASI PROGRAM PEMBINAAN RENANG DI KLUB TIRTA SERAYU, TCS, BUMI PALA, DEZENDER, SPECTRUM DI PROVINSI JAWA TENGAH
}

\section{THE EVALUATION OF POOL DEVELOPMENT PROGRAM AT TIRTA SERAYU CLUB, BUMI PALA, DEZENDER, AND SPECTRUM IN CENTRAL JAVA PROVINCE}

\author{
Ardhika Falaahudin, Sugiyanto \\ MTs YAPPI Pakem, Universitas Negeri Yogyakarta \\ dhika_falaah@yahoo.com,fx.sugiyanto56@yahoo.co.id
}

\begin{abstract}
Abstrak
Penelitian ini bertujuan untuk mengevaluasi konteks, input, process dan Produk pelaksanaan program pembinaan olahraga renang di Tirta Serayu, TCS, Bumi Pala, Dezender, Spectrum di Provinsi Jawa Tengah. Subjek penelitian ini adalah atlet yang pernah mengikuti kejuaraan renang tingkat Nasional di klub renang Tirta Serayu Banjarnegara, TCS Semarang, Bumi Pala Temanggung, Dezender Purbalingga dan Spectrum Semarang, pelatih dan orangtua atlet yang berjumlah 15 orang. Teknik pengumpulan data menggunakan metode observasi, wawancara, angket dan dokumentasi. Teknik analisis data dalam penelitian ini yaitu análisis deskriptif kuantitatif dan kualitatif. Hasil penelitian menunjukkan bahwa secara keseluruhan hasil evaluasi program pembinaan olahraga renang klub renang Tirta Serayu, TCS, Bumi Pala, Dezender, Spectrum di Provinsi Jawa Tengah sudah baik, meliputi: (1) evaluasi konteks dukungan dari orang tua atlet kepada atlet sudah baik, (2) evaluasi input, secara umum sumber daya manusia untuk mencapai tujuan program pembinaan olahraga renang meliputi pelatih, atlet, dan pendukung lainnya seperti sarana dan prasarana dan kualifikasi pelatihan telah memenuhi ketercapaian ideal. Meskipun untuk tingkat pendidikan pelatih serta sarana dan prasarana masih ada yang belum memadai, (3) evaluasi proses, secara umum telah berjalan dengan baik. Dalam pemilihan program setiap klub renang sebelumnya menganalisis program yang telah berjalan dengan mempertimbangkan kondisi di lapangan, pelatih telah mengikuti petunjuk teknis pelaksanaan program serta terdapat jadwal rutin dan target latihan serta dilaksanakan latih tanding, try out dengan klub atau atlet dari klub lain dan juga berperan aktif mengikuti kejuaraan, (4) evaluasi Produk, secara garis besar prestasi klub renang di Provinsi Jawa Tengah yang dicapai para atletnya terbilang sangat baik, dibuktikan dengan prestasi yang telah diraih melalui tingkat daerah, provinsi, nasional bahkan ASEAN.
\end{abstract}

Kata kunci: Evaluasi program, pembinaan olahraga renang

\begin{abstract}
This study was aimed to evaluate the context, input, process and Produk for the implementation of swimming sports coaching program at Tirta Serayu, TCS, Bumi Pala, Dezender, Spectrum in Central Java Province. The subjects were the athletes who attended the national championships level at the swimming pool club of Tirta Serayu Banjarnegara, TCS Semarang, Bumi Pala Temanggung, Dezender Purbalingga and Spectrum Semarang, the coaches and the athletes' parents totaled of 15 persons. Data collection techniques were using observation, interviews, questionnaires and documentation. Data analysis techniques were using quantitative and qualitative descriptive analysis. The results showed that generally the evaluation of the implementation of swimming sports development program at Tirta Serayu, TCS, Bumi Pala, Dezender, Spectrum in Central Java Province was good which consisted of (1) In the evaluation context it was good for the parents support for the athlete. (2) For the input evaluation, generally it met the ideal achievement for the human resources to achieve sports coaching program objectives included swimming coaches, athletes, and other supporting facilities and infrastructure such as training qualification, although the level of the coaches education and facilities were not adequate. (3) In the evaluation process, the implementation of swimming club training program in Central Java province generally had been going well. In the program election, each swimming club analyzing the running program based on the field and coaches who had followed the instructions and regular schedule, target practice and the practice match implementation, try out the clubs or athletes from other clubs and also actively follow the championship. (4) On the Produk evaluation, generally the performance of swimming clubs in the province of Central Java achieved by the athletes were fairly good, this was evidenced by some of the achievements that have been achieved through local, provincial, national and even ASEAN.
\end{abstract}

Keywords: program evaluation, swimming sports development program 


\section{Pendahuluan}

Dalam keseharian, manusia selalu bergerak. Hal ini disebabkan oleh berbagai tuntutan kebutuhan kehidupan maupun fisik maupun fisiologi. Ditinjau dari aspek fisik-fisiologi atau biologis, bergeraknya manusia merupakan tuntutan yang alamiah. Bahkan sebagian organ tubuh bergerak secara ritmik yang tidak dapat diatur oleh kehendak manusia sendiri. Secara social-psikologis manusia bergerak untuk memenuhi kebutuhan secara sadar dan terencana bahkan diatur dan ditata menurut aturan dan etika yang berlaku. Oleh Karena itu, bergeraknya manusia yang ditandai oleh hilir-mudik perpindahan, dan kesibukan aktivitas fisik untuk bekerja dan lainnya merupakan ragam mobilitas manusia.

Berenang adalah gerakan sewaktu bergerak di air. Berenang biasanya dilakukan tanpa menggunakan alat bantu. Kegiatan ini dapat dimanfaatkan untuk rekreasi dan olahraga. Berenang dipakai sewaktu bergerak dari satu tempat ke tempat lainnya di air, mencari ikan, mandi, atau melakukan olahraga air. Berenang untuk keperluan rekreasi dan kompetisi dilakukan di kolam berenang. Manusia juga berenang di sungai, danau, dan laut sebagai bentuk rekreasi. Olahraga berenang membuat tubuh sehat karena hampir semua otot tubuh dipakai sewaktu berenang.

Menurut Kamus Lengkap Bahasa Indonesia, kata olahraga merupakan kata kerja yang diartikan gerak badan agar sehat. Sedang menurut para pakar olahraga, adalah sebuah aktivitas manusia yang bertujuan untuk mencapai kesejahteraan (sejahtera jasmani dan sejahtera rohani) manusia itu sendiri. Dalam aktivitas olahraga tentu ada aspek positif dan negatifnya. Aspek positifnya, yaitu (1) Mampu menggerakkan aktivitas sosial, ekonomi, dan politik: adanya interaksi antarmanusia (individu dan kelompok), adanya kegiatan jasa, adanya penyerapan tenaga kerja. (2) Mampu mengangkat harga diri pelaku olahraga/atlet/pelatih/pembina/organisasi/daerah dan bangsa, kesejahteraan pembina olahraga, dan martabat bangsa di dunia internasional. Sedang aspek negatifnya, antara lain seperti masih adanya kecenderungan dari banyak atlet dalam mengikuti suatu pertandingan menggunakan segala cara dalam upaya memenangkan pertandingan/perlombaan, misalnya tidak fair play, tidak disiplin, memanipulasi, melanggar ketentuan (peraturan pertandingan/perlombaan), dan pemakaian doping.
Olahraga adalah sebuah kata dalam bahasa Inggris yang berarti olahraga. Sedang sportif yang merupakan kata sifat yang berarti jujur dan ksatria atau gagah. Sementara kata sportivitas yang sebagai kata benda mempunyai arti orang yang melakukan olahraga tersebut (harus) memiliki kejujuran dan sikap ksatria dalam bertindak dan berprilaku saat berolahraga, seperti disiplin, mengikuti ketentuan dan peraturan yang telah ditetapkan atau yang telah disepakati bersama, terutama saat mengikuti suatu pertandingan atau perlombaan olahraga.

Sistem pembangunan olahraga tidak bisa dengan cara instan tetapi membutuhkan totalitas dan komitmen untuk membina olahraga secara sistematik dan mendukung. Prestasi olahraga merupakan sesuatu yang tampak dan teratur, artinya bahwa pembinaan olahraga dilakukan dengan pendekatan secara ilmiah mulai dari pemanduan bakat hingga proses pembinaan. Ketika dilihat dari kacamata kesisteman bahwa kualitas hasil (out put) ditentukan oleh masukan (input) dan kualitas proses pembinaan yang terjadi. Prestasi yang selama ini didapatkan merupakan konsekuensi nyata dari subsistem yang kurang optimal yaitu input dan proses (Cholik, 2007, p.4).

Pembinaan dan pembangunan olahraga prestasi dilaksanakan dan diarahkan untuk mencapai prestasi olahraga pada tingkat daerah, nasional dan internasional. Pembinaan dilakukan oleh induk organisasi cabang olahraga baik pada tingkat daerah maupun pada tingkat pusat. Pembinaan juga dilaksanakan dengan memberdayakan perkumpulan olahraga, menumbuh kembangkan sentra pembinaan olahraga yang bersifat nasional dan daerah serta menyelenggarakan kompetisi secara berjenjang dan berkelanjutan (Undang-undang nomor 3 tahun 2005).

Suryatna dan Suherman (2004, p.4) mendefinisikan kompetisi yaitu persaingan yang dapat mendorong keberhasilan atau prestasi seseorang. Kompetisi juga berarti suatu keadaan yang berlawanan dengan kerja sama, terutama pada kegiatan yang bersifat tunggal atau individual, menurut Supandi (1997) (Suryatna dan Suherman 2004, p.4). Kompetisi terdiri atas dua jenis yaitu; (1) persaingan tak langsung, dan (2) persaingan langsung. Persaingan tak langsung berupa standar tanpa lawan, sedangkan persaingan langsung melibatkan lawan secara langsung sehingga ada upaya untuk mengungguli prestasi lawan. Persaingan yang dihadapi siswa seperti disekolah, sebagian besar berupa persaingan langsung antara sesamanya 
untuk memperoleh nilai atau prestasi belajar lebih unggul, dilingkungan masyarakat, siswa juga diharapkan pada sejumlah persaingan dalam aktivitas kehidupan nyata sehari-hari.

Upaya peningkatan prestasi olahraga perlu terus dilaksanakan dengan pembinaan olahragawan sendiri mungkin melalui pencarian dan pemantauan bakat, pembibitan, pendidikan dan pelatihan olahraga prestasi yang didasarkan pada ilmu pengetahuan dan teknologi secara lebih efektif serta peningkatan kualitas organisasi olahraga, baik tingkat pusat maupun daerah. Olahraga prestasi dilaksanakan melalui proses pembinaan dan pengembangan secara terencana, berjenjang, dan berkelanjutan dengan dukungan ilmu pengetahuan dan teknologi keolahragaan (Undang-undang nomor 3 tahun 2005 pasal 20).

Pencapaian prestasi dalam olahraga diperlukan usaha dan program yang sistematis dalam jalur pembinaan secara terprogram, berjenjang, dan berkelanjutan. Sistem pembinaan olahraga pretasi yang lebih efektif termasuk pemberian penghargaan bagi olahragawan terutama atlet dan pelatih berpotensi dan berprestasi serta pengembangan organisasi-organisasi keolahragaan dan wadah-wadah pembinaan yang lain perlu mendapat prioritas dalam rangka mempertahankan dan meningkatkan kualitas keolahragaan nasional. Keberhasilan dalam proses pembinaan atlet berbakat untuk mencetak atlet berprestasi sangat bergantung pada penerapannya kedalam sistem penyelenggaraan pelatihan.

Salah satu penyelenggaraan proses pembinaan adalah klub olahraga, dalam proses pembinaan olahraga menuju prestasi optimal, klub (perkumpulan olahraga) berada pada posisi strategis, hal tersebut dikarenakan klub olahraga berada pada posisi terdepan yang secara operasional melakukan pembinaan langsung kepada atlet dalam bentuk proses latihan, sehingga dapat dikatakan bahwa klub olahraga merupakan ujung tombak pembinaan olahraga prestasi.

Bila dicermati diberbagai kegiatan olahraga, maka akan ditemukan unsur bermain, unsur latihan fisik dan unsur pertandingan atau kompetisi. Melalui bermain akan dapat dikembangkan berbagai sifat positif seperti: sportif, jujur, disiplin, demokratis, menghargai peraturan, dan percaya diri. Pemerintah Republik Indonesia telah menetapkan arah dan kebijakan nasional dalam pembinaan dan pengembangan olahraga dalam Undang-Undang No. 3 Tahun 2005 menyatakan: "Pemerintah dan Pemerintah
Daerah wajib melakukan pembinaan dan pengembangan olahraga sesuai dengan kewenangan dan tanggung jawabnya. Pemerintah melakukan pembinaan dan pengembangan olahraga melalui penetapan kebijakan, penataran/pelatihan, koordinasi, konsultasi, komunikasi, penyuluhan, pembimbingan, pemasyarakatan, perintisan, penelitian, uji coba, kompetisi, pemudahan, perizinan dan pengawasan".

Menurut Suchman (1961, dalam Anderson 1975, dalam Arikunto 2010, p.1) memandang evaluasi sebagai sebuah proses menentukan hasil yang telah dicapai beberapa kegiatan yang direncanakan untuk mendukung tercapainya tujuan. Proses evaluasi harus dilaksanakan secara komprehensif agar hasilnya benar-benar dapat dijadikan dasar dalam menentukan kualitas dari suatu program. Hal ini berarti evaluasi dijadikan secara menyeluruh untuk menilai unsur-unsur yang mendukung dari sebuah program.

Sebuah program bukan hanya kegiatan tunggal yang dapat diselesaikan dalam waktu singkat, tetapi merupakan kegiatan yang berkesinambungan karena melaksanakan suatu kebijakan. Oleh karena itu, sebuah program dapat berlangsung dalam kurun waktu relatif lama. Pelaksanaan program selalu terjadi dalam sebuah organisasi yang artinya harus melibatkan sekelompok orang.

Salah satu penyelenggaraan proses pembinaan adalah klub yang di kelola pengurus cabang (Pengcab) dan pengurus daerah (Pengda), dalam proses pembinan olahraga menuju prestasi optimal, klub (perkumpulan olahraga) berada pada posisi strategis, hal tersebut dikarenakan klub olahraga berada pada posisi terdepan yang secara operasional melakukan pembinaan langsung kepada atlet dalam bentuk proses latihan, sehingga dapat dikatakan bahwa klub olahraga merupakan ujung tombak pembinaan olahraga prestasi.

Khususnya Jawa Tengah adalah salah satu provinsi yang mempunyai klub renang terbanyak yaitu sekitar 46 klub dari berbagai kabupaten, dari ke 46 klub tersebut ada yang memiliki atlet yang sudah maju ke taraf nasional maupun internasional, yaitu (1) Tirta Serayu Banjarnegara yang sudah menjuarai ASEAN University Games di Laos dengan mendapat juara 2, (2) TCS Semarang yang sudah menjuarai KRAPSI di Bandung dengan mendapat juara 1, (3) Bumi Pala Temanggung yang sudah menjuarai INVINAS di Surabaya dengan mendapatkan juara 1, (4) Dezender Purbalingga yang 
sudah menjuarai KRAPSI di Jakarta dengan mendapatkan juara 3, (5) Spectrum Semarang yang sudah menjuarai KRAPSI di Karanganyar dengan mendapat juara 1. Dari kelima klub renang tersebut adalah klub terbaik di Jawa Tengah yang selalu menghasilkan atlet-atlet berprestasi.

Menurut pengamatan penulis dari beberapa kompetisi internasional, khususnya di cabang renang belum menunjukkan hasil yang optimal atau yang diinginkan. Dilihat dari hasil sea games 2011 lalu dari cabang renang, Indonesia hanya bisa memperoleh 24 medali diantaranya enam emas, delapan perak dan sepuluh perunggu.

Kelima klub di atas mempunyai prestasi yang berbeda beda. Untuk itu peneliti melakukan evaluasi program pembinaan yang ada di kelima klub itu untuk mengetahui hasil pembinaan yang ada di klub renang tersebut, yang nantinya akan dijadikan sebagai bahan perbaikan program pembinaan.

\section{Metode}

\section{Jenis Penelitian}

Sesuai dengan tujuan penelitian, jenis penelitian ini dikategorikan sebagai penelitian evaluasi. Penelitian evaluasi merupakan kegiatan penelitian untuk mengumpulkan data, menyajikan informasi yang akurat dan objektif mengenai pembinaan olahraga renang di klub Tirta Serayu, TCS, Bumi Pala, Dezender, Spectrum di Provinsi Jawa Tengah, berdasarkan akurasi dan objektivitas informasi yang diperoleh selanjutnya dapat menentukan nilai atau tingkat keberhasilan program, sehingga bermanfaat untuk pemecahan masalah serta mempertimbangkan apakah program tersebut perlu dilanjutkan atau dimodifikasi. Desain penelitian ini adalah deskriptif non hipotesis.

Penelitian ini menggunakan pendekatan campuran atau kombinasi atau menggabungkan antara metode kuantitatif dan metode kualitatif untuk digunakan secara bersama-sama dalam suatu kegiatan penelitian. Sugiyono (2011, p.404) menyatakan bahwa metode penelitian kombinasi adalah suatu metode penelitian yang mengkombinasikan atau menggabungkan antara metode kuantitatif dan metode kualitatif untuk digunakan secara bersama-sama dalam suatu kegiatan penelitian, sehingga diperoleh data yang lebih komperhensif, valid, reliabel dan obyektif. Penelitian kualitatif dapat membantu memberikan informasi dasar tentang konteks dan subyek, berlaku sebagai sumber hipotesis, dan membantu kontruksi skala (Brannen, 2005, p.84).

\section{Tempat dan Waktu Penelitian}

Penelitian ini dilaksanakan di klub renang Tirta Serayu Banjarnegara (Kolam renang Serulingmas Banjarnegara), TCS Semarang (Gelanggang renang Jati Diri Semarang), Bumi Pala Temanggung (Kolam renang Pikatan Temanggung), Dezender Purbalingga (Kolam renang Walik Purbalingga) dan Spectrum Semarang (Kolam renang Manunggal Jati Semarang) selama 2 bulan dari bulan Januari 2013 sampai Februari 2013.

Target/Subjek Penelitian

Populasi menurut Sukmadinata (2005, p.250) kelompok besar dan wilayah yang menjadi lingkup penelitian. Menurut Suharsimi (2010, p.173) populasi adalah keseluruhan subjek penelitian. Populasi penelitian ini adalah semua atlet yang pernah mengikuti kejuaraan renang tingkat nasional di klub renang Tirta Serayu Banjarnegara, TCS Semarang, Bumi Pala Temanggung, Dezender Purbalingga dan Spectrum Semarang, Pelatih dan orang tua atlet tersebut.

Subjek dalam penelitian ini adalah: 5 orang atlet klub renang Tirta Serayu, TCS, Bumi Pala, Dezender dan Spectrum, 5 orang tua altet klub renang Tirta Serayu, TCS, Bumi Pala, Dezender dan Spectrum, (5 orang pelatih klub renang Tirta Serayu, TCS, Bumi Pala, Dezender dan Spectrum, yang semuanya berjumlah 15 orang. Atlet dalam penelitian ini minimal sudah mengikuti INVINAS dan mendapatkan medali, sedangkan pelatih dalam penelitian ini adalah yang sudah memiliki lesensi kepelatihan.

\section{Prosedur}

Prosedur atau teknik pengumpulan data merupakan langkah yang paling strategis dalam penelitian, karena tujuan utama dari penelitian adalah mendapatkan data. Tanpa mengetahui teknik pengumpulan data, maka peneliti tidak akan mendapatkan data yang memenuhi standar data yang ditetapkan. Bila dilihat dari segi cara atau teknik pengumpulan data, maka teknik pengumpulan data dapat dilakukan dengan observasi (pengamatan), interview, kuesioner (angket), dokumentasi dan gabungan keempatnya (Sugiyono, 2010, pp.308-309).

Untuk memperoleh data primer dalam penelitian ini, digunakan pengumpul data beru- 
pa observasi, wawancara, sedangkan dokumentasi berupa arsip yang ada digunakan sebagai data pendukung atau data sekunder.

Observasi merupakan salah satu metode yang dapat digunakan untuk memperoleh informasi tentang fokus penelitian. Fokus pengamatan dapat berupa peristiwa, perilaku dan ekspresi orang-orang dalam keadaan (setting) dimana peneliti berada. Pada metode ini diperlukan kepekaan peneliti terhadap situasi atau setting tempat melakukan pengamatan (Norman $\&$ Creswell, 2010, p.156).

Ada beberapa alasan mengapa dalam penelitian kualitatif, pengamatan dimanfaatkan sebesar-besarnya seperti yang dikemukakan oleh (Guba dan Lincoln, 1981, p.174 dalam Moleong, 2010, p.74) sebagai berikut ini. Pertama, teknik pengamatan ini didasarkan atas pengalaman secara langsung. Kedua, teknik pengamatan juga memungkinkan melihat dan mengamati sendiri, kemudian mencatat perilaku dan kejadian sebagaimana yang terjadi pada keadaan sebenarnya. Ketiga, pengamatan memungkinkan peneliti mencatat peristiwa dalam situasi yang berkaitan dengan pengetahuan proporsional maupun pengetahuan yang diperoleh langsung dari data. Keempat, sering terjadi ada keraguan pada peneliti, jangan-jangan pada data yang dijaringnya ada yang keliru atau bias. $\mathrm{Ke}$ lima, teknik pengamatan memungkinkan peneliti mampu memahami situasi-situasi yang rumit. Keenam, dalam kasus-kasus tertentu dimana teknik komunikasi lainnya tidak dimungkinkan, pengamatan dapat menjadi alat yang sangat bermanfaat.

Wawancara adalah percakapan dengan maksud tertentu. Percakapan itu dilakukan oleh dua pihak, yaitu pewawancara (interviewer) yang mengajukan pertanyaan dan terwawancara (interviewees) yang memberikan jawaban atas pertanyaan itu (Moleong, 2010, p.186), sedangkan Sukarjo (2006, p.22) mendefinisikan wawancara adalah salah satu jenis pengumpulan dan pencatatan data informasi, dan atau pendapat yang dilakukan melalui percakapan dan tanya jawab, baik langsung maupun tidak langsung dengan sumber data.

Pada saat wawancara dimulai, perlu pembicaraan pendahuluan (warming up) untuk perkenalan dan menjelaskan tujuan wawancara. Wawancara dilakukan dengan menggunakan bahasa sederhana dan mudah dimengerti.Topik permasalahan sebaiknya yang menarik dan sesuai minat/keahlian responden. Wawancara dilakukan dalam suasana bebas dan santai. Laku- kan stimulasi percakapan dan hati-hati untuk hal sensitive serta menjaga rahasia. Latihan menjadi pewawancara yang baik, meliputi 2 tahap: Tahap I: Pewawancara mempelajari pedoman wawancara, mempelajari kondisi wawancara: transpotasi, pengamanan data, variabel yang diungkap, dll; Tahap II: Pewawancara dilatih menjadi pewawancara yang baik: bagaimana dating, membuka percakapan, mengemukakan maksud, mengajukan pertanyaan, memberikan respon, sampai menutup pembicaraan. Wawancara harus efektif sehingga dalam waktu singkat diperoleh data sebanyak-banyaknya. (Saryono, 2011, p.80).

Dokumentasi merupakan kegiatan mencari data atau variabel dari sumber berupa catatan, transkip, buku, majalah, prasasti, notulen rapat, agenda dan sebagainya, yang diamati dalam studi dokumentasi adalah benda mati. Peneliti perlu checklist untuk mencatat variabel yang sudah ditentukan (Saryono, 2011, p.81). Dokumentasi untuk memperkuat data yang diperoleh dengan wawancara dan pengamatan langsung (observasi), peneliti juga menggunakan teknik dokumentasi didalam pengumpulan data.

Angket adalah alat untuk mengumpulkan dan mencatat data atau informasi (Sukarjo, 2006, p.25). Angket adalah teknik pengumpulan data dengan menyerahkan atau mengirimkan daftar pertanyaan yang digunakan untuk memperoleh data dari responden, dalam arti laporan tentang pribadinya atau hal-hal lain yang diketahui. Teknik pengumpulan data melalui formulir-formulir yang berisi pertanyaan-pertanyaan yang diajukan secara tertulis pada seseorang atau sekumpulan orang untuk mendapatkan jawaban atau tanggapan dan informasi yang diperlukan oleh peneliti (Djoyosuroto dan Sumaryati, 2010, p.50).

\section{Teknik Analisis Data}

Pada prinsipnya analisis data ada dua cara yaitu analisis data statistik dan analisis data non statistik, hal ini tergantung pada datanya. Adapun analisis data non statistik, yang disebut juga analisis kualitatif yaitu analisis yang tidak menggunakan model matematik, model statistik dan ekonometrik atau model-model tertentu lainnya. Analisis data dilakukan terbatas pada metode pengolahan datanya, seperti pada pengecekan data dan tabulasi, dalam hal ini sekedar membaca tabel-tabel, grafik-grafik, atau angka-angka yang tersedia kemudian melakukan uraian dan penafsiran, sedangkan analisis 
data statistik yang disebut juga análisis kuantitatif yaitu análisis yang mempergunakan alat análisis bersifat kuantitatif. Alat análisis yang bersifat kuantitatif adalah alat análisis yang menggunakan model-model, seperti model matematika (misalnya fungsi multi varíate), model statistik dan ekonometrik. Hasil analisis disajikan dalam bentuk angka-angka yang kemudian dijelaskan dan diinterpretasikan dalam suatu uraian (Hasan, 2002, p.98).

Teknik analisis data yang digunakan dalam penelitian evaluasi ini adalah analisis diskriptif kuantitatif dan kualitatif, dengan mendiskripsikan dan mamaknai data dari masingmasing komponen yang dievaluasi baik data kuantitatif maupun data kualitatif. Data dari instrumen angket dianalisis dengan cara kuantitatif dan data dari hasil wawancara akan dianalisis secara kualitatif.

\section{Hasil Penelitian dan Pembahasan}

Jawa Tengah merupakan salah satu provinsi di Indonesia yang terletak di tengah pulau Jawa. Secara geografis, Provinsi Jawa Tengah terletak antara $5^{\circ} 40^{\prime}$ dan $8^{\circ} 30^{\prime}$ Lintang Selatan dan antara $108^{\circ} 30^{\prime} 111^{\circ} 30^{\prime}$ Bujur Timur (termasuk pulau Karimunjawa). Provinsi ini berbatasan dengan Laut Jawa di sebelah Utara, Samudra Hindia dan D.I. Yogyakarta di sebelah Selatan, Provinsi Jawa Barat di sebelah Barat, dan Provinsi Jawa Timur di sebelah Timur. Luas wilayahnya tercatat sebesar 3,25 juta hektar atau sekitar 25,04 persen dari luas pulau Jawa dan 1,70 persen dari luas Indonesia.

Dalam penelitian ini terdapat 15 orang informan penelitian. Subjek penelitian ini meliputi: 5 atlet renang, 5 pelatih renang dan 5 orang tua atlet renang yang mewakili masingmasing klub renang di Tirta Serayu, TCS, Bumi Pala, Dezender, Spectrum di Provinsi Jawa Tengah.

Berdasarkan hasil penelitian menunjukkan bahwa secara keseluruhan pada hasil evaluasi konteks, input, proses dan produk pada pelaksanaan program pembinaan olahraga renang klub renang Tirta Serayu, TCS, Bumi Pala, Dezender, Spectrum di Provinsi Jawa Tengah sudah baik. Hal ini dapat dilihat pada indikator orang tua atlet, pelatih, atlet, sarana prasarana, kualifikasi pelatihan, program pelatihan dan prestasi yang dicapai.

Klub olahraga merupakan ujung tombak pembinaan olahraga prestasi. Hal ini dikarenakan klub olahraga melakukan pembinaan langsung kepada atlet. Oleh karena itu, untuk mengetahui proses pelaksanaan pembinaan klub olahraga perlu melakukan evaluasi. Hal ini sebagaimana pendapat Stufflebeam (2003, p.10) yang mengemukakan bahwa:

"evaluation is the process of delineating, and providing descriptive and judgmental information about the worth and merit of some object's goals, design, implementation, and impact in order to guide decision making, serve needs for accountability, and promote understanding of the involved phenomena".

Melalui evaluasi, klub olahraga mendapatkan informasi yang dapat dijadikan sebagai bahan pertimbangan dalam pengambilan keputusan.

Evaluasi konteks merupakan merupakan kemampuan awal suatu keadaan dalam menunjang suatu program. Menurut Sudjana (2008, p.54) evaluasi konteks menjelaskan mengenai kondisi lingkungan yang relevan, menggambarkan kondisi yang ada dan yang diinginkan dalam lingkungan, dan mengidentifikasi kebutuhan-kebutuhan yang belum terpenuhi dan peluang yang belum dimanfaatkan. Pendapat tersebut juga didukung oleh Stufflebeam (2003, p.2) bahwa context evaluations assess needs, problems, assets, and opportunities to help decision makers define goals and priorities and help the broader group of users judge goals, priorities, and outcomes. Evaluasi kontexs ini membantu menentukan kebutuhan yang akan dicapai oleh program.

Dukungan dari orang tua atlet merupakan konteks yang tidak kalah penting bagi atlet. Karena dengan adanya izin, motivasi, dan dukungan secara penuh baik materi maupun non materi, maka atlet akan menjadi lebih bersemangat dalam latihan dan kejuaraan olahraga renang, yang pada akhirnya dapat meningkatkan keberhasilan dalam prestasi. Oleh karena itu, perlu adanya peran aktif dari orang tua atlet untuk mendukung prestasi atlet.

Secara keseluruhan indikator orang tua atlet renang di klub renang di Provinsi Jawa Tengah telah memberikan dukungan dan motivasi baik secara materil maupun non materil kepada atlet. Motivasi merupakan salah satu komponen penting dalam psikologi olahraga dan mempengaruhi tinggi rendahnya prestasi atlet. Hal ini berarti atlet yang memiliki motivasi yang tinggi sangat berpeluang mencapai puncak prestasi puncaknya, sebaliknya atlet yang tidak memiliki motivasi akan sulit mewujudkan prestasi puncak. 
Selain itu, atlet juga perlu sumber dukungan lainnya seperti dukungan pemerintah dan masyarakat. Dukungan pemerintah dapat berupa pemberian sarana dan prasarana yang dapat menunjang olahraga renang seperti adanya kolam renang yang sesuai standar dan menyediakan tempat pemondokan (asrama) bagi atlet. Sementara dukungan masyarakat dapat berupa donasi (pemberian dana) bagi atlet yang berprestasi dan peran serta aktif dalam olahraga. Dengan demikian konteks dukungan orang tua atlet merupakan hal penting bagi atlet, baik dalam bentuk izin, motivasi, dan dukungan materi maupun non materi, sehingga atlet dapat mencapai prestasi secara optimal. Berikut disajikan tabel evaluasi konteks.

Tabel 1. Evaluasi Konteks di Klub Renang Tirta Serayu

\begin{tabular}{|c|c|c|c|c|}
\hline & \multirow{2}{*}{ Indikator/Sub Indikator } & \multicolumn{3}{|c|}{ Ketercapaian } \\
\hline & & B & $\mathbf{C}$ & $\mathbf{K}$ \\
\hline \multicolumn{5}{|c|}{ Orang Tua Atlet } \\
\hline 1) & $\begin{array}{l}\text { Izin/dukungan orang tua atlet } \\
\text { untuk menekuni olahraga } \\
\text { renang }\end{array}$ & 3 & & \\
\hline 2) & Motivasi orang tua kepada atlet & 3 & & \\
\hline 3) & $\begin{array}{l}\text { Ketersediaan fasilitas yang } \\
\text { memadai }\end{array}$ & 3 & & \\
\hline 4) & $\begin{array}{l}\text { Keluhan selama proses } \\
\text { pelatihan kepada orang tua }\end{array}$ & & 2 & \\
\hline \multicolumn{5}{|c|}{$\begin{array}{l}\text { Keterangan: Baik }(B)=3 \text {, Cukup }(C)=2, \text { Kurang } \\
(\mathrm{K})=1 \text {, (Sumber: Hasil wawancara, } 2013)\end{array}$} \\
\hline \multicolumn{5}{|c|}{ Tabel 2. Evaluasi Konteks di Klub Renang TCS } \\
\hline \multirow{2}{*}{\multicolumn{2}{|c|}{ Indikator/Sub Indikator }} & \multicolumn{3}{|c|}{ Ketercapaian } \\
\hline & & $\mathbf{B}$ & $\mathbf{C}$ & $\mathbf{K}$ \\
\hline \multicolumn{5}{|c|}{ Orang Tua Atlet } \\
\hline & $\begin{array}{l}\text { Izin/dukungan orang tua atlet } \\
\text { untuk menekuni olahraga } \\
\text { renang }\end{array}$ & 3 & & \\
\hline & Motivasi orang tua kepada atlet & 3 & & \\
\hline 3) & $\begin{array}{l}\text { Ketersediaan fasilitas yang } \\
\text { memadai }\end{array}$ & 3 & & \\
\hline 4) & $\begin{array}{l}\text { Keluhan selama proses } \\
\text { pelatihan kepada orang tua }\end{array}$ & & & 1 \\
\hline
\end{tabular}

Tabel 3. Evaluasi Konteks di Klub Renang Bumi Pala

\begin{tabular}{|c|c|c|c|c|}
\hline & \multirow{2}{*}{ Indikator/Sub Indikator } & \multicolumn{3}{|c|}{ Ketercapaian } \\
\hline & & $\mathbf{B}$ & $\mathbf{C}$ & $\mathbf{K}$ \\
\hline \multicolumn{5}{|c|}{ Orang Tua Atlet } \\
\hline 1) & $\begin{array}{l}\text { Izin/dukungan orang tua atlet } \\
\text { untuk menekuni olahraga } \\
\text { renang }\end{array}$ & 3 & & \\
\hline 2) & Motivasi orang tua kepada atlet & 3 & & \\
\hline 3) & $\begin{array}{l}\text { Ketersediaan fasilitas yang } \\
\text { memadai }\end{array}$ & 3 & & \\
\hline 4) & $\begin{array}{l}\text { Keluhan selama proses } \\
\text { pelatihan kepada orang tua }\end{array}$ & 3 & & \\
\hline
\end{tabular}

Keterangan: Baik $(\mathrm{B})=3$, Cukup $(\mathrm{C})=2$, Kurang $(\mathrm{K})=1$, (Sumber: Hasil wawancara, 2013)

Tabel 4. Evaluasi Konteks di Klub Renang Dezender

\begin{tabular}{|c|c|}
\hline \multirow{2}{*}{ Indikator/Sub Indikator } & Ketercapaian \\
\hline & $\begin{array}{lll}\text { B } & \text { C } & \text { K }\end{array}$ \\
\hline
\end{tabular}

1) Izin/dukungan orang tua atlet 3 untuk menekuni olahraga renang

2) Motivasi orang tua kepada atlet 3

3) Ketersediaan fasilitas yang 2 memadai

4) Keluhan selama proses 2 pelatihan kepada orang tua

Keterangan: Baik $(\mathrm{B})=3$, Cukup $(\mathrm{C})=2$, Kurang $(\mathrm{K})=1$, (Sumber: Hasil wawancara, 2013)

Tabel 5. Evaluasi Konteks di Klub Renang Spectrum

\begin{tabular}{|c|c|}
\hline & Ketercapaian \\
\hline Indikator/sub Indikator & $\begin{array}{lll}\text { B } & \text { C } & \text { K }\end{array}$ \\
\hline
\end{tabular}

1) Izin/dukungan orang tua atlet 3 untuk menekuni olahraga renang

2) Motivasi orang tua kepada atlet 3

3) Ketersediaan fasilitas yang 3 memadai

4) Keluhan selama proses 3 pelatihan kepada orang tua

Keterangan: Baik $(B)=3$, Cukup $(C)=2$, Kurang $(\mathrm{K})=1$, (Sumber: Hasil wawancara, 2013)

Evaluasi input merupakan kegiatan untuk menganalisis sumber daya manusia untuk mencapai tujuan program, dalam hal ini adalah pelatih, atlet, dan pendukung lainnya seperti sarana dan prasarana dan kualifikasi pelatihan. Hal ini sesuai dengan pendapat Sudjana (2008, p.55) bahwa evaluasi konteks yaitu menyediakan data untuk menentukan bagaimana penggunaan sumber-sumber yang dapat digunakan untuk mencapai tujuan program. 
Pendapat tersebut juga senada dengan yang dikemukakan oleh Stufflebeam (2003, p.3) bahwa input evaluations assess alternative approaches, competing action plans, staffing plans, and budgets for their feasibility and potential cost-effectiveness to meet targeted needs and achieve goals. Sumber-sumber yang dapat digunakan untuk tujuan program pembinaan olahraga renang meliputi pelatih, atlet, kelayakan sarana dan prasarana serta kualifikasi pelatihan.

Evaluasi input dalam penelitian ini meliputi indikator pelatih, atlet, sarana dan prasarana serta kualifikasi pelatihan yang ada di klub renang Tirta Serayu, TCS, Bumi Pala, Dezender, Spectrum di Provinsi Jawa Tengah.

Tabel 6. Evaluasi Input di Klub Renang Tirta Serayu

\begin{tabular}{clcc}
\hline \multirow{2}{*}{ No } & \multirow{2}{*}{ Indikator/Sub Indikator } & \multicolumn{2}{c}{ Ketercapaian } \\
\cline { 3 - 4 } & Belatih & $\mathbf{C}$ & $\mathbf{K}$ \\
\hline 1 & Pel & & \\
& a) Tingkat pendidikan & 3 & \\
b) Sertifikat program & 3 & \\
c) Membuat program latihan & 3 & \\
d) Mantan atlet & 3 &
\end{tabular}

2 Atlet
a) Kondisi fisik
b) Usia
c) Potensial
3

3

3

3 Kelayakan sarana dan prasarana

4 Kualifikasi pelatihan

3

Keterangan: Baik $=3$, Cukup $=2$, Kurang $=1$

(Sumber: Hasil angket terbuka, dokumentasi dan observasi, 2013)

Tabel 7. Evaluasi Input di Klub Renang TCS

\begin{tabular}{lllll}
\hline \multirow{2}{*}{ No } & \multirow{2}{*}{ Indikator/Sub Indikator } & \multicolumn{3}{c}{ Ketercapaian } \\
\cline { 3 - 4 } & & B & C & K \\
\hline 1 & Pelatih & & \\
& a) & Tingkat pendidikan & 3 & \\
& b) Sertifikat program & 3 & \\
& c) Membuat program latihan & 3 & \\
& d) Mantan atlet & 3 & \\
\end{tabular}

2 Atlet
a) Kondisi fisik
b) Usia
c) Potensial
3
3
3 Kelayakan sarana dan prasa- 3 rana
$4 \quad$ Kualifikasi pelatihan 3

Keterangan: Baik $=3$, Cukup $=2$, Kurang $=1$

(Sumber: Hasil angket terbuka, dokumentasi dan observasi, 2013)
Tabel 8.Evaluasi Input

di Klub Renang Bumi Pala

\begin{tabular}{lllll}
\hline \multirow{2}{*}{ No } & \multirow{2}{*}{ Indikator/Sub Indikator } & \multicolumn{3}{c}{ Ketercapaian } \\
\cline { 3 - 4 } & & B & C & K \\
\hline 1) & Pelatih & & & \\
a) Tingkat pendidikan & & 2 & \\
b) Sertifikat program & 3 & & \\
c) Membuat program latihan & 3 & \\
d) Mantan atlet & 3 &
\end{tabular}

$2 \quad$ Atlet
a) Kondisi fisik
3
b) Usia
c) Potensial

3 Kelayakan sarana dan prasarana

$4 \quad$ Kualifikasi pelatihan

3

Keterangan: Baik $=3$, Cukup $=2$, Kurang $=1$

(Sumber: Hasil angket terbuka, dokumentasi dan observasi, 2013)

Tabel 9. Evaluasi Input di Klub Renang Dezender

\begin{tabular}{|c|c|c|c|c|}
\hline \multirow{2}{*}{ No } & \multirow{2}{*}{ Indikator/Sub Indikator } & \multicolumn{3}{|c|}{ Ketercapaian } \\
\hline & & B & $\mathbf{C}$ & $\mathbf{K}$ \\
\hline \multirow[t]{5}{*}{ 1) } & Pelatih & & & \\
\hline & a) Tingkat pendidikan & & 2 & \\
\hline & b) Sertifikat program & 3 & & \\
\hline & c) Membuat program latihan & 3 & & \\
\hline & d) Mantan atlet & 3 & & \\
\hline \multirow[t]{4}{*}{2} & Atlet & & & \\
\hline & a) Kondisi fisik & 3 & & \\
\hline & b) Usia & 3 & & \\
\hline & c) Potensial & 3 & & \\
\hline 3 & $\begin{array}{l}\text { Kelayakan sarana dan prasa- } \\
\text { rana }\end{array}$ & & & 1 \\
\hline 4 & Kualifikasi pelatihan & 3 & & \\
\hline
\end{tabular}

Keterangan: Baik $=3$, Cukup $=2$, Kurang $=1$

(Sumber: Hasil angket terbuka, dokumentasi dan observasi, 2013)

Tabel 10. Evaluasi Input di Klub Renang Spectrum

\begin{tabular}{|c|c|c|c|c|}
\hline \multirow{2}{*}{ No } & \multirow{2}{*}{ Indikator/Sub Indikator } & \multicolumn{3}{|c|}{ Ketercapaian } \\
\hline & & B & $\mathbf{C}$ & $\mathbf{K}$ \\
\hline \multirow[t]{5}{*}{ 1) } & Pelatih & & & \\
\hline & e) Tingkat pendidikan & 3 & & \\
\hline & f) Sertifikat program & 3 & & \\
\hline & g) Membuat program latihan & 3 & & \\
\hline & h) Mantan atlet & 3 & & \\
\hline \multirow[t]{4}{*}{2} & Atlet & & & \\
\hline & d) Kondisi fisik & 3 & & \\
\hline & e) Usia & 3 & & \\
\hline & f) Potensial & 3 & & \\
\hline 3 & $\begin{array}{l}\text { Kelayakan sarana dan } \\
\text { prasarana }\end{array}$ & & & 1 \\
\hline 4 & Kualifikasi pelatihan & 3 & & \\
\hline
\end{tabular}


Evaluasi input menunjukkan bahwa indikator pelatih jika dilihat dari tingkat pendidikan belum memenuhi derajat ketercapaian yang ideal karena tingkat pendidikan pelatih 5 klub renang di Provinsi Jawa Tengah masih terdapat yang lulusan SMA sebanyak 2 orang (40\%), sedangkan yang SI sebanyak 2 orang (40\%) dan S2 sebanyak 1 orang (20\%). Sementara untuk sertifikasi pelatih seluruhnya sudah berlisensi dan merupakan mantan atlet serta telah membuat program latihan. Kualifikasi pelatihan juga sudah baik karena terdapat jadwal rutin dan target yang harus dicapai atlet. Kemudian indikator atlet secara keseluruhan sudah baik dari segi kondisi fisik, usia produktif dan potensial.

Selanjutnya indikator kelayakan sarana dan prasarana masih terdapat beberapa klub renang di Provinsi Jawa Tengah yang belum memenuhi standar. Misalnya ukuran kolam renang yang dimiliki klub renang Dezender belum berstandar, klub renang Spectrum belum terdapat fasilitas head coach dan coach, klub renang Tirta Serayu belum memiliki alat $d r y$ land dan pare clock digital, serta klub renang Bumi Pala juga belum tersedia dokter atau psikolog untuk membantu kesehatan atlet.

Peranan pelatih dalam olahraga tidak bisa dipisahkan dari tujuan yang akan dicapai yakni mencapai prestasi yang optimal. Tanpa pelatih yang bermutu dan berkualitas dapat menyebabkan prestasi yang didambakan akan sulit tercapai. Latar belakang pelatih klub renang di Provinsi Jawa Tengah agar memenuhi derajat ketercapaian yang ideal sebaiknya memiliki tingkat pendidikan yang memadai minimal S1, pelatih merupakan mantan atlit, pelatih memiliki sertifikasi yang berlisensi baik dan pelatih membuat program dan target latihan.

Atlet merupakan objek utama dari proses pembinaan olahraga prestasi jangka panjang. Hal-hal yang perlu diperhatikan berkaitan dengan atlet adalah kondisi fisik, usia dan potensi. Oleh karena itu, prestasi puncak bagi seorang atlet sangat ditentukan oleh banyak faktor. Prestasi para atlet merupakan hasil perpaduan beberapa faktor yakni faktor fisik, teknis, struktur maupun kepribadian. Agar atlet mencapai prestasi yang optimal, sebaiknya klub renang harus memperhatikan faktor fisik, teknis, struktur maupun kepribadian bagi atlet.

Selain sumber daya manusia, faktor sarana dan prasarana merupakan suatu katalisator atau penghubung untuk mewujudkan suatu prestasi yang diinginkan. Oleh karena itu, sarana dan prasaran olahraga renang sebaiknya memenuhi syarat-syarat baik kualitas maupun kuantitas. Kualifikasi pelatihan juga perlu untuk selalu ditingkatkan dengan membuat program latihan secara rutin dan target serta mengikuti perlombaan-perlombaan.

Dengan demikian input pelatih, atlet, kelayakan sarana dan prasarana serta kualifikasi pelatihan sangat penting dalam program pembinaan olahraga klub renang di Provinsi Jawa Tengah.

Evaluasi proses merupakan evaluasi yang diarahkan pada seberapa jauh kegiatan yang dilaksanakan di dalam program. Dalam hal ini akan dilihat tepat tidaknya pelaksanaan suatu program yang telah ditetapkan. Suharsimi dan Cepi (2009, p.47) mengemukakan evaluasi proses diarahkan pada seberapa jauh kegiatan yang dilaksanakan di dalam program sudah terlaksana sesuai dengan rencana. Pendapat tersebut juga sesuai dengan pendapat Stufflebeam (2003, p.3) bahwa process evaluations assess the implementation of plans to help staff carry out activities and later help the broad group of users judge program performance and interpret outcomes.

Untuk mencapai prestasi yang optimal tidak datang begitu saja, namun melalui proses, salah satu proses yang dilalui yaitu program latihan. Program latihan adalah proses berjenjang dan berkelanjutan yang mempunyai sasaran yang jelas, terukur dan dapat dipertanggungjawabkan.

Oleh karena itu, program latihan sangat penting bagi atlet untuk mencapai kesuksesan. Kesuksesan atlet pada umumnya merupakan hasil dari program latihan yang benar dan dalam jangka panjang. Program latihan jangka panjang ini berfungsi untuk meningkatkan kondisi jiwa dan raga saat berkompetisi dalam sebuah kejuaraan. Evaluasi proses dalam penelitian ini berupa program pelatihan yang dilakukan klub renang Tirta Serayu, TCS, Bumi Pala, Dezender, Spectrum di Provinsi Jawa Tengah.

Evaluasi proses klub renang di Provinsi Jawa Tengah secara umum telah berjalan dengan baik. Dalam pemilihan program setiap klub renang sebelumnya menganalisis program yang telah berjalan dengan mempertimbangkan kondisi dilapangan serta pelatih telah mengikuti Juknis pelaksanaan program dan terdapat jadwal rutin dan target latihan.

Untuk mendukung keberhasilan atletnya dilaksanakan latih tandaing, try out dengan klub atau atlet dari klub lain dan juga berperan aktif mengikuti kejuaraan lain baik di tingkat 
kota, daerah, regional, nasional bahkan ada yang mendapatkan juara pada tingkat ASEAN di Laos tahun 2012.

Tabel 11. Evaluasi Proses di Klub Renang Tirta Serayu

\begin{tabular}{|c|c|c|c|c|}
\hline \multirow{2}{*}{\multicolumn{2}{|c|}{ Indikator/Sub Indikator }} & \multicolumn{3}{|c|}{ Ketercapaian } \\
\hline & & $\mathbf{B}$ & $\mathbf{C}$ & $\mathbf{K}$ \\
\hline \multicolumn{5}{|c|}{ Program Pelatihan } \\
\hline a) & $\begin{array}{l}\text { Pemilihan pelaksanaan } \\
\text { program }\end{array}$ & 3 & & \\
\hline b) & $\begin{array}{l}\text { Pelatih mengikuti Juknis } \\
\text { pelaksanaan program }\end{array}$ & 3 & & \\
\hline c) & $\begin{array}{l}\text { Adanya jadwal rutin dan target } \\
\text { latihan }\end{array}$ & 3 & & \\
\hline
\end{tabular}

Keterangan: Baik $=3$, Cukup $=2$, Kurang $=1$

(Sumber: Hasil angket terbuka, dokumentasi dan observasi, 2013)

Tabel 12. Evaluasi Proses di Klub Renang TCS

\begin{tabular}{|c|c|c|c|c|}
\hline \multirow{2}{*}{\multicolumn{2}{|c|}{ Indikator/Sub Indikator }} & \multicolumn{3}{|c|}{ Ketercapaian } \\
\hline & & B & C & $\mathbf{K}$ \\
\hline \multicolumn{5}{|c|}{ Program Pelatihan } \\
\hline a) & $\begin{array}{l}\text { Pemilihan pelaksanaan } \\
\text { program }\end{array}$ & 3 & 2 & \\
\hline b) & $\begin{array}{l}\text { Pelatih mengikuti Juknis } \\
\text { pelaksanaan program }\end{array}$ & 3 & & \\
\hline c) & $\begin{array}{l}\text { Adanya jadwal rutin dan target } \\
\text { latihan }\end{array}$ & & & \\
\hline
\end{tabular}

Keterangan: Baik $=3$, Cukup $=2$, Kurang $=1$ (Sumber: Hasil angket terbuka, dokumentasi dan observasi, 2013)

Tabel 13. Evaluasi Proses di Klub Renang Bumi Pala

\begin{tabular}{|c|c|c|c|c|}
\hline \multirow{2}{*}{\multicolumn{2}{|c|}{ Indikator/Sub Indikator }} & \multicolumn{3}{|c|}{ Ketercapaian } \\
\hline & & B & $\mathbf{C}$ & $\mathbf{K}$ \\
\hline \multicolumn{5}{|c|}{ Program Pelatihan } \\
\hline a) & $\begin{array}{l}\text { Pemilihan pelaksanaan } \\
\text { program }\end{array}$ & 3 & & \\
\hline b) & $\begin{array}{l}\text { Pelatih mengikuti Juknis } \\
\text { pelaksanaan program }\end{array}$ & 3 & & \\
\hline c) & $\begin{array}{l}\text { Adanya jadwal rutin dan target } \\
\text { latihan }\end{array}$ & 3 & & \\
\hline
\end{tabular}

Keterangan: Baik $=3$, Cukup $=2$, Kurang $=1$ (Sumber: Hasil angket terbuka, dokumentasi dan observasi, 2013)
Tabel 14. Evaluasi Proses di Klub Renang Dezender

\begin{tabular}{lll}
\hline \multirow{2}{*}{ Indikator/Sub Indikator } & \multicolumn{2}{c}{ Ketercapaian } \\
\cline { 2 - 3 } & $\mathbf{B} \mathbf{C} \mathbf{K}$ \\
\hline $\begin{array}{l}\text { Program Pelatihan } \\
\text { a) Pemilihan pelaksanaan }\end{array}$ & 3 \\
$\begin{array}{l}\text { program } \\
\text { b) Pelatih mengikuti Juknis } \\
\text { pelaksanaan program }\end{array}$ & 3 \\
c) Adanya jadwal rutin dan target & 3 \\
$\quad$ latihan & \\
\hline
\end{tabular}

Keterangan: Baik $=3$, Cukup $=2$, Kurang $=1$ (Sumber: Hasil angket terbuka, dokumentasi dan observasi, 2013)

Tabel 15. Evaluasi Proses di Klub Renang Spectrum

\begin{tabular}{lll}
\hline \multirow{2}{*}{ Indikator/Sub Indikator } & \multicolumn{2}{c}{ Ketercapaian } \\
\cline { 2 - 3 } & B & $\mathbf{C} \quad \mathbf{K}$ \\
\hline $\begin{array}{l}\text { Program Pelatihan } \\
\text { d) } \begin{array}{l}\text { Pemilihan pelaksanaan } \\
\text { program }\end{array}\end{array}$ & 3 \\
e) $\begin{array}{l}\text { Pelatih mengikuti Juknis } \\
\text { pelaksanaan program }\end{array}$ & 3 \\
f) $\begin{array}{l}\text { Adanya jadwal rutin dan target } \\
\text { latihan }\end{array}$ & 3 \\
\hline
\end{tabular}

Keterangan: Baik $=3$, Cukup $=2$, Kurang $=1$ (Sumber: Hasil angket terbuka, dokumentasi dan observasi, 2013)

Evaluasi Produk merupakan hasil yang telah dicapai. Hal ini sesuai dengan pendapat Stufflebeam (2003, p.3) bahwa

Produk evaluations identify and assess outcomes intended and unintended, short term and long term both the help a staff keep an enterprise focused on achieving importans outcomes and ultimately to help the broader group of users gauge the effort's success in meeting targeted needs.

Pendapat tersebut juga sesuai dengan pendapat Sudjana (2008, p.56) bahwa evaluasi produk mengukur dan menginterpretasi pencapaian program selama pelaksanaan program dan pada akhir program.

Prestasi olahraga tidak dapat diperoleh dengan mudah dan instan. Untuk mencapai prestasi dalam olahraga diperlukan usaha maksimal dari berbagai pihak yang terkait dan waktu yang panjang. Usaha untuk mencapai prestasi optimal dipengaruhi oleh kualitas latihan, sedangkan kualitas latihan ditentukan oleh berbagai faktor pendukung antara lain: kemampuan dan kepribadian pelatih, fasilitas dan peralatan, hasil-hasil penelitian, kompetisi dan kemampuan atlet yang meliputi bakat dan motivasi, serta 
pemenuhan gizi dan gaya hidup atlet (KONI DIY, 2005, p.17).

Evaluasi Produk dalam penelitian ini meliputi indikator prestasi yang diraih klub renang Tirta Serayu, TCS, Bumi Pala, Dezender, Spectrum di Provinsi Jawa Tengah.

Tabel 16. Evaluasi Produk di Klub Renang Tirta Serayu

\begin{tabular}{llll}
\hline \multirow{2}{*}{ Indikator/Sub Indikator } & \multicolumn{3}{c}{ Ketercapaian } \\
\cline { 2 - 4 } & & $\mathbf{B}$ & $\mathbf{K}$ \\
\hline $\begin{array}{l}\text { Prestasi/keberhasilan evaluasi } \\
\text { program pembinaan }\end{array}$ & & & \\
1) Hasil program pembinaan & 3 & & \\
2) Prestasi daerah & & 2 & \\
3) Prestasi Regional & & 2 & \\
4) Prestasi Nasional & 3 & & \\
5) Prestasi Asean & & & 1 \\
6) Prestasi Asia & & & 1
\end{tabular}

Keterangan: Baik $=3$, Cukup $=2$, Kurang $=1$, (Sumber: Hasil dokumentasi, 2013)

Tabel 17. Evaluasi Produk di Klub Renang TCS

\begin{tabular}{|c|c|c|c|c|}
\hline & \multirow{2}{*}{ Indikator/Sub Indikator } & \multicolumn{3}{|c|}{ Ketercapaian } \\
\hline & & B & $\mathbf{C}$ & $\mathbf{K}$ \\
\hline \multicolumn{5}{|c|}{$\begin{array}{l}\text { Prestasi/keberhasilan evaluasi } \\
\text { program pembinaan }\end{array}$} \\
\hline 1) & Hasil program pembinaan & 3 & & \\
\hline 2) & Prestasi daerah & & & 1 \\
\hline 3) & Prestasi Regional & & & 1 \\
\hline 4) & Prestasi Nasional & 3 & & \\
\hline 5) & Prestasi Asean & & & 1 \\
\hline & Prestasi Asia & & & 1 \\
\hline
\end{tabular}

Keterangan: Baik $=3, \quad$ Cukup $=2, \quad$ Kurang $=1$, (Sumber: Hasil dokumentasi, 2013)

Tabel 18. Evaluasi Produk di Klub Renang Bumi Pala

\begin{tabular}{clll}
\hline \multirow{2}{*}{ Indikator/Sub Indikator } & \multicolumn{2}{l}{ Ketercapaian } \\
\cline { 2 - 3 } & B & C $\quad$ K \\
\hline
\end{tabular}

Prestasi/keberhasilan evaluasi program pembinaan
1) Hasil program pembinaan
2
2) Prestasi daerah
3) Prestasi Regional
4) Prestasi Nasional 3
5) Prestasi Asean
6) Prestasi Asia 1

Keterangan: Baik $=3$, Cukup $=2$, Kurang $=1$, (Sumber: Hasil dokumentasi, 2013)
Tabel 19. Evaluasi Produk di Klub Renang Dezender

\begin{tabular}{ccccc}
\hline \multirow{2}{*}{ Indikator/Sub Indikator } & \multicolumn{3}{c}{ Ketercapaian } \\
\cline { 3 - 4 } & B & C & K \\
\hline
\end{tabular}

Prestasi/keberhasilan evaluasi program pembinaan

1) Hasil program pembinaan 2

2) Prestasi daerah

3) Prestasi Regional 1

4) Prestasi Nasional 2

5) Prestasi Asean 3

6) Prestasi Asia

Keterangan: Baik $=3$, Cukup $=2$, Kurang $=1$, (Sumber: Hasil dokumentasi, 2013)

Tabel 20. Evaluasi Produk di Klub Renang Spectrum

\begin{tabular}{|c|c|c|c|}
\hline \multirow{2}{*}{ Indikator/Sub Indikator } & \multicolumn{3}{|c|}{ Ketercapaian } \\
\hline & B & $\mathrm{C}$ & $\mathbf{K}$ \\
\hline $\begin{array}{l}\text { Prestasi/keberhasilan evaluasi } \\
\text { program pembinaan }\end{array}$ & & & \\
\hline 7) Hasil program pembinaan & 3 & & \\
\hline 8) Prestasi daerah & 3 & & \\
\hline 9) Prestasi Regional & 3 & & \\
\hline 10)Prestasi Nasional & 3 & & \\
\hline 11)Prestasi Asean & & & 1 \\
\hline 12)Prestasi Asia & & & 1 \\
\hline
\end{tabular}

Keterangan: Baik $=3$, Cukup $=2$, Kurang $=1$, (Sumber: Hasil dokumentasi, 2013)

Secara garis besar prestasi klub renang di Provinsi Jawa Tengah yang dicapai para atletnya terbilang sangat baik, hal ini dibuktikan dengan beberapa prestasi yang telah diraih melalui tingkat daerah, provinsi, nasional bahkan ASEAN. Produk yang dihasilkan dari klub renang di Provinsi Jawa Tengah dapat dijadikan contoh bagi daerah Provinsi lain. Hasil ini juga tidak terlepas dari program pembinaan yang dilakukan sehingga berdampak pada kualitas atlet.

Untuk mencapai prestasi yang optimal tidak datang begitu saja, namun melalui proses, salah satu proses yang dilalui yaitu program latihan. Program latihan adalah proses berjenjang dan berkelanjutan yang mempunyai sasaran yang jelas, terukur dan dapat dipertanggungjawabkan. Oleh karena itu, program latihan sangat penting bagi atlet untuk mencapai kesuksesan. Kesuksesan atlet pada umumnya merupakan hasil dari program latihan yang benar dan dalam jangka panjang. Program latihan jangka panjang ini berfungsi untuk meningkatkan kondisi jiwa dan raga saat berkompetisi dalam sebuah kejuaraan.

Untuk mencapai prestasi yang tertinggi di bidang olahraga diperlukan latihan teratur, meningkat dan berkesinambungan dalam waktu 
yang cukup lama, yaitu antara 8 sampai dengan 12 tahun. Latihan harus dimulai sejak usia dini dan mencapai puncak prestasi antara umur 18 sampai dengan 25 tahun. Dalam sistem pembinaan olahraga jangka panjang, tahap awal dimulai dengan memasalkan olahraga di seluruh kalangan masyarakat dengan semboyan yang sudah dicanangkan pemerintah yaitu "memasyarakatkan olahraga dan mengolahragakan masyarakat". Di kalangan internasional dikenal dengan istilah "Sport For All". Setelah olahraga menjadi masal, akan banyak bermunculan bibit berbakat. Melalui berbagai pendekatan ilmiah, dipilih bibit berbakat untuk setiap cabang olahraga, yang kemudian dipandu untuk mencapai prestasi setinggi-tingginya.

Organisasi sistem olahraga nasional harus mendefinisikan tujuan yang akan dicapai. Tujuan utama dari sistem olahraga nasional dapat dirinci menjadi tujuan-tujuan yang lebih kecil dalam setiap pentahapan yang harus dilakukan.

Dengan demikian untuk menghasilkan atlet yang berprestasi sebaiknya program latihan memegang prinsip berjenjang, berkelanjutan dan dimulai sejak dini serta adanya adanya sumber daya yang bersinergi antara pelatih, atlet, kelayakan sarana dan prasarana, pemerintah dan masyarakat.

\section{Simpulan dan Saran}

Simpulan

Evaluasi konteks menunjukkan dukungan dari orang tua atlet kepada atlet sudah baik, yakni dengan adanya izin, motivasi, dan dukungan secara penuh baik materi maupun non materi, sehingga atlet menjadi lebih bersemangat dalam latihan dan kejuaraan olahraga renang.

Evaluasi input menunjukkan secara umum sumber daya manusia untuk mencapai tujuan program pembinaan olahraga renang meliputi pelatih, atlet, dan pendukung lainnya seperti sarana dan prasarana dan kualifikasi pelatihan telah memenuhi ketercapaian ideal. Meskipun untuk tingkat pendidikan pelatih serta sarana dan prasarana masih belum memadai.

Evaluasi proses menunjukkan pelaksanaan program latihan klub renang di Provinsi Jawa Tengah secara umum telah berjalan dengan baik. Dalam pemilihan program setiap klub renang sebelumnya menganalisis program yang telah berjalan dengan mempertimbangkan kondisi di lapangan serta pelatih telah meng- ikuti Juknis pelaksanaan program dan terdapat jadwal rutin dan target latihan. Untuk mendukung keberhasilan atletnya dilaksanakan latih tanding, try out dengan klub atau atlet dari klub lain dan juga berperan aktif mengikuti kejuaraan lain.

Evaluasi Produk menunjukkan bahwa secara garis besar prestasi klub renang di Provinsi Jawa Tengah yang dicapai para atletnya terbilang sangat baik, hal ini dibuktikan dengan beberapa prestasi yang telah diraih melalui tingkat daerah, provinsi, nasional bahkan ASEAN.

Saran

Hendaknya evaluasi CIPP diterapkan oleh klub renang agar dapat dijadikan pertimbangan dalam pengambilan keputusan.

Conteks, input, process dan Produk klub renang Tirta Serayu, TCS, Bumi Pala, Dezender, Spectrum di Provinsi Jawa Tengah tidak memiliki perbedaan (sama), sehingga atlet dapat menggunakan kelima klub tersebut untuk meningkatkan prestasi olahraga renang.

Hendaknya pelatih terus mengembangkan ilmu kepelatihannya dengan cara memenuhi syarat-syarat ideal sebagai pelatih dan mengikuti pelatihan-pelatihan, sehingga dapat menciptakakan atlet-atlet yang berprestasi.

Hendaknya pemerintah Provinsi Jawa Tengah memberikan dukungan baik dalam bentuk kebijakan program pembinaan olahraga renang maupun dalam bentuk sarana dan prasarana olahraga yang memadai sesuai standar internasional yang dapat mendukung atlet mampu berprestasi.

Penelitian ini berupa evaluasi pelaksanaan program pembinaan olahraga renang, hendaknya peneliti selanjutnya dapat meneliti tentang analisis SWOT untuk cabang olahraga renang, sehingga dapat dijadikan pedoman bagi klub renang dalam menyusun program pembinaan sesuai dengan kondisi terkini.

\section{Daftar Pustaka}

Arikunto, Suharsimi. (2010). Prosedur penelitian: Suatu pendekatan praktek. Jakarta: Rineka cipta.

Arikunto, Suharsimi \& Cepi, S.A.J. (2009). Evaluasi program pendidikan. Jakarta: Bumi Aksara.

Brannen, Julia. (2005). Memadu metode penelitian. Yogyakarta: Pustaka Pelajar. 
Djoyosuroto dan Sumaryati. (2010). Prinsipprinsip dasar penelitian bahasa dan sastra. Jakarta: Nuansa Yayasan Nusantara Cendekia.

Hasan, Iqbal. (2002). Pokok-pokok materi metodologi penelitian dan aplikasinya. Jakarta: Ghalia Indonesia.

KEMENPORA. (2005). Undang-Undang RI Nomor 3 Tahun 2005, Sistem Keolahragaan Nasional.

KONI Daerah Istimewa Yogyakarta. (2005). Panduan pembinaan olahraga prestasi Koni DIY. Yogyakarta: KONI DIY.

Cholik Mutohir, Toho dan Maksun, Ali. (2007). Sport development index, alternatif baru mengukur kemajuan pembangunan bidang keolahragaan. Jakarta: PT Indeks.
Stufflebeam, D. L. \& Shinkfield, A. J. (1985). Systematic evaluation. Buston: Allyn and Bacon.

Sudjana, Djudju. (2008). Evaluasi program pendidikan luar sekolah. Bandung: PT. Remaja Rosdakarya.

Sugiyanto, FX \& Agus. S. (2005). Dasar gerak renang. Yogyakarta: Universitas Negeri Yogyakarta.

Sugiyono. (2010). Metode penelitian pendidikan: Pendekatan kuantitatif, kualitatif dan $R \quad \& \quad D$. Bandung: Alfabeta Bandung. . (2011). Metode penelitian kombinasi (Mixed Methods). Bandung: Alfabeta Bandung.

Sukmadinata, Nana Syaodih. (2005). Metode penelitian pendidikan. Bandung: Remaja Rosdakarya. 